\title{
Issues of Democratic Development and Construction of National Identity at the End of the Age of Imitations: Editorial Introduction
}

\author{
P. Dutkiewicz ${ }^{1}$, Yu.M. Pochta ${ }^{2}$ \\ ${ }^{1}$ Carleton University, Ottawa, Canada \\ ${ }^{2}$ Peoples' Friendship University of Russia (RUDN University), \\ Moscow, Russian Federation
}

\begin{abstract}
In the article, the guest editor Piotr Dutkiewicz and editor-in-chief Yuriy M. Pochta introduce the current issue of the journal, interpreting cross-cutting topics such as democratic development and the construction of national identity in the societies of the East and the West. They believe that the most appropriate heuristic explanation for these issues today is the idea that after the end of the Cold War the hopes for the final victory of the liberal democratic project on a global scale ended in disappointment. The end of history never took place, just like the victory of communism did not take place previously. All these years we have been witnessing an imitation of liberalism, the era of which is already over. There is currently a global revolt against the liberal imitation imperative. From this point of view, there is a great interest in articles devoted to Russian-Turkish relations, the place of the Central Asian states in the international rankings of democratic development, the evolution of the political development of the Lebanese Republic, the formation of democratic political regimes in such Eastern European EU member states as Poland and Hungary, the role of parties in the political life of Great Britain and Nigeria, as well as such theoretical and methodological problems of political science as the processes of forming future political leaders, methodology of the study of GR-management and approaches to the study of the political and psychological characteristics of the heads of Russian regions. In general, this issue of the journal pictures the current state of democratic development of Western and non-Western countries in the context of globalization, which is at the stage of transition from American monopolarity to multipolarity, from imitation of the Western liberal-democratic project to the search for its own development projects. The authors believe that from the point of view of Russia and its interests the materials of this issue allow for outlining the prospects for further research on ways to build the most effective relations with world and regional powers, the possibilities of protecting its sovereignty and its geopolitical interests, and the mechanisms for forming the Russian post-Soviet identity at the national and regional levels.
\end{abstract}

Keywords: democracy, ideology, geopolitics, right-wing radicalism, regionalism, GR-management, political parties, national identity, elite, Russia, Turkey, Lebanon, European Union, Great Britain, Poland, Hungary

(C) Dutkiewicz P., Pochta Yu.M., 2021 
For citation: Dutkiewicz, P., \& Pochta, Yu.M. (2021). Issues of democratic development and construction of national identity at the end of the age of imitations: Editorial introduction. RUDN Journal of Political Science, 23(3), 339-347. DOI: 10.22363/2313-1438-2021-23-3-339-347

\title{
Вопросы демократического развития и конструирования национальной идентичности в конце эпохи имитаций: представляем номер
}

\author{
П. Дуткевич ${ }^{1}$ Ю.М. Почта ${ }^{2}$ \\ ${ }^{1}$ Карлтонский университет, Оттава, Канада \\ ${ }^{2}$ Российский университет дружбы народов, Москва, Российская Федерация
}

\begin{abstract}
Аннотация. В статье приглашенный редактор П. Дуткевич и главный редактор журнала Ю.М. Почта представляют материалы номера, трактуя их сквозную тематику как вопросы демократического развития и конструирования национальной идентичности в обществах Востока и Запада. По их мнению, наиболее подходящим эвристическим объяснением этих вопросов сегодня может служить представление о том, что после окончания холодной войны разочарованием закончились надежды на окончательную победу либерально-демократического проекта в глобальном масштабе. Конец истории не состоялся аналогично не состоявшейся до этого победе коммунизма. Все эти годы мы наблюдали имитационный либерализм, эпоха которого уже закончилась. В настоящее время происходит глобальное восстание против либерального имитационного императива. Под этим углом зрения представляют несомненный интерес статьи, посвященные российско-турецким отношениям, месту государств Центральной Азии в международных рейтингах развития демократии, эволюции политического развития Ливанской Республики, становлению демократических политических режимов в таких восточноевропейских странах - членах $\mathrm{EC}$, как Польша и Венгрия, роли партий в политической жизни Великобритании и Нигерии, а также таким теоретико-методологическим проблемам политической науки, как процессы формирования будущих политических лидеров, методология изучения GR-менеджмента и подходы к изучению политико-психологических особенностей глав российских регионов. В целом данный номер журнала дополняет картину современного состояния демократического развития западных и незападных стран в условиях глобализации, находящейся на стадии перехода от американской монополярности к многополярности, от имитации западного либерально-демократического проекта к поискам собственных проектов развития. Представляя краткий обзор статей, составивших тему номера журнала, авторы полагают, что с точки зрения интересов России материалы этого номера позволяют наметить перспективы дальнейших исследований способов выстраивания наиболее эффективных отношений с мировыми и региональными державами, возможностей защиты своего суверенитета и своих геополитических интересов, механизмов формирования российской постсоветской идентичности на национальном и региональном уровнях.
\end{abstract}

Ключевые слова: демократия, идеология, геополитика, правый радикализм, регионализм, GR-менеджмент, политические партии, национальная идентичность, элита, Россия, Турция, Ливан, Европейский союз, Великобритания, Польша, Венгрия

Для цитирования: Dutkiewicz P., Pochta Yu.M. Issues of democratic development and construction of national identity at the end of the age of imitations: Editorial introduction // Вестник Российского университета дружбы народов. Серия: Политология. 2021. Т. 23. № 3. С. 339-347. DOI: $10.22363 / 2313-1438-2021-23-3-339-347$ 
The issues of democratic development and the construction of national identity remain relevant for both Western and Eastern societies. They also dragged the attention of the authors, who contributed to the current issue of our journal.

In order to explain the contents of our journal, we would like to refer to the ideas expressed by Bulgarian political scientist Ivan Krastev and American lawyer Stephen Holmes in their book "The Light That Failed: Why the West is Losing the Fight for Democracy". They consider that the hopes for a complete and final victory of the liberal-democratic project on a global scale after the end of the Cold War ended in disappointment: "Liberalism ended up the victim of its heralded success in the Cold War" [Krastev, Holmes 2019:16]. Post-communist states only imitated liberal democracy, while their leaders eventually began to publicly deny and criticize liberal values. Thirty years after the collapse of the Soviet Union and the socialist camp, it became evident, that what we had during these years was not the actual implementation of the principles of liberal democracy, but only their mimicry and imitation. It was the imitation of liberalism, the age of which is over. Currently, there is a global uprising against the liberal imitation imperative.

Post-Soviet Russia made one of its first attempts at independent participation in world politics in 2015, combining diplomatic efforts with the use of its armed forces in order to stop the destabilization of statehood in Syria and to counter international terrorism. However, Russia's return to the Middle East affected the interests of a number of states, in particular, Turkey, which took an active part in the Syrian crisis. Russia, seeking to regain its role as one of the leading participants in Middle Eastern politics, inevitably collided with the interests of Turkey. However, Syria represents only a small part of the sphere of Turkey's geopolitical interests, where Russian and Turkish interests collide. It is also necessary to consider the global context of Russian-Turkish relations.

Disappointed in its hitherto failed entry into the EU, under the moderate Islamist leadership of Erdogan, moving away from the republican legacy of Ataturk towards neo-Ottomanism, Turkey is becoming a regional power and is trying to take control over some of the former regions of the Ottoman Empire. It claims to be the leader of the Turkic peoples, preserving traditional Islamic values and striving to implement one of the projects of political Islam in the Muslim world. Currently, Turkey, under the authoritarian leadership of President Tayyip Erdogan, combines the desire to integrate into the Western world with one of preserving its own identity. Considering the American Greater Middle East project, Turkey is inevitably forced to seek pragmatic partnership with Russia. According to Russian international journalist Andrey Isaev, in case the United States are dissatisfied with Erdogan's policy, "it is not impossible for others to come into power in Turkey professing the ideals of either Euro-Atlanticism or a world caliphate"1. The partnership between Russia and Turkey is important for ensuring the security of the

\footnotetext{
${ }^{1}$ Isaev, A. The US-Turkish summit in Brussels: the moment of truth or the point of no return? The International Affairs. Retrieved June 07, 2021, from https://interaffairs.ru/news/show/30368 (in Russian).
} 
two countries. At the same time, it can be argued that after a century-long break, the rivalry between the successors of the Russian and Ottoman empires is taking new forms, rejecting the dictates of the liberal-democratic project of globalization and seeking to use their own civilizational heritage. The idea of Ivan Krastev and Stephen Holmes that "the withdrawal of peoples into barricaded national and ethnic communities is one of the consequences of today's populist and identity-based war on universalism" [Krastev, Holmes 2019:318] is quite suitable for Russia and Turkey. A vivid example of the rivalry between Russia and Turkey is the competition between their two integration projects - the Eurasian integration and the neo-Ottoman integration. The representatives of the elites of Turkic post-Soviet states are attracted to the idea of returning to their historical roots under the leadership of Turkey, which offers a trans-regional integration project connecting a number of post-Soviet states to liberal-democratic globalization as part of the Turkic-Islamic world. Taking into account this current complicated context, our reader may be interested in the article by V.A. Avatkov and P.A. Gudev researchers from the Center for post-Soviet Studies of The Institute of World Economy and International Relations after Primakov National Research Institute of World Economy and International Relations (IMEMO) of the Russian Academy of Sciences, which analyzes the geopolitical factor in Russian-Turkish relations and examines the main problems of Russian-Turkish cooperation in the Black Sea area in the context of the restoration of bilateral relations after the 2015 incident, related to Russia's participation in the Syrian crisis.

The above-mentioned allows to comprehend how difficult it is to establish statehood in the post-Soviet societies, which, shortly after the collapse of the Soviet Union, started rejecting the Soviet in favor of the liberal-democratic project. They have no choice but to construct their new identity, eclectically combining elements of such identities as Western liberal-democratic, religious (Islamic), ethnic (Turkic), civilizational (neo-Ottoman), anti-colonialist and anti-imperialist (most often aimed against Russia, which is interpreted as a former metropolis). As a result, by leaving the sphere of Russian influence, these states fall under the influence of either the dominant global West or regional powers, primarily Turkey, as well as China. Turkey offers its own trans-regional project, combining moderate Westernization with a basis on civilizational heritage as part of the Turkic-Islamic world. Some representatives of the elites of these states are looking for an opportunity to enter the global world through the trans-regional structure created by Turkey on the basis of the neo-Ottoman Turkic identity. The overview by E.G. Garbuzarova, a researcher from the Political Science Department of the Kyrgyz-Russian Slavic University (Bishkek), regards democratic development assessment in the post-Soviet space on the example of the Central Asian states, showing the placement of these states in international democracy development ratings. The author concludes, that, according to the ratings, having abandoned the ideology of Marxism, the Central Asian states sought to implement a liberal political ideology and follow the path of democratic transit. However, the 
introduction of the basic elements of democracy into the political process of the countries turned out to be of formal or declarative nature, while the participation of the masses in politics still remains strictly limited.

Radical Arab nationalism and the ideology of socialism failed to resolve the pressing socio-economic issues of several Middle Eastern countries that became republics after gaining independence. Traditional monarchical regimes turned out to be more stable. Under this ideological vacuum, political Islam (Sunni and Shiite, moderate and radical) started leading in the political life of Middle Eastern countries. This was also facilitated by the destabilization of several states as a result of foreign interventions, as well as the desire of the oil-producing monarchies of the region with large financial resources to preserve their authoritarian political regimes and extend their influence to other countries of the Muslim world [Pochta 2020]. According to Russian islamologist Gumer Isaev, the destabilization of the Greater Middle East and its radical Islamization will entail serious consequences, manifested in the decline of "the era of local modernism associated with nationalism, Westernization, in an attempt to build a political system based on the Western model, but taking into account cultural specifics"”.

We presume that the specifics of political life in this region, especially after the upheavals of the "Arab spring", is that local players (states, ethno-religious groups, opposition movements, terrorist groups) do not have stable allied ties, their contacts are situational, they depend on external influences, on the evolution of the interests of clans, tribes and authoritarian leaders. In countries such as Lebanon, brief periods of fragile political stability can quickly be replaced by violent clashes (civil wars) between various ethnic, ethno-religious, religious, tribal structures, as well as within these structures (between Arabs themselves, between the Lebanese and Palestinian refugees, between Arabs and Iranians, between Shiites and Sunnis, between Christians and Muslims, etc.). In addition, neighboring states such as Syria and Israel, as well as Iran, have had and continue to have a great impact on Lebanese politics. Their intervention can significantly determine the development of the internal political situation in Lebanon. The abovementioned showcases the difficulties of Lebanon's development. A.A. Kerimov, an employee of the Russian Embassy in the Lebanon, analyzes the democratic development of the Lebanese Republic based on a comparison of the political life of this country with the ideal consociational democracy model by A. Leiphart in order to identify the country's specific features and find ways to overcome the expanding instability. The author shows the internal and external causes of the Lebanese political crises, assesses the possible ways of evaluating the country's political regime, including the prospects for the transformation of consociational democracy into a general civil democracy.

The European Union also encounters problems with democratic development. Discussions on the problems and internal contradictions of the European integration

\footnotetext{
${ }^{2}$ Isaev, G. The collapse of the Arab dream. What is the future of the nation States of the Middle East. Retrieved December 27, 2015, from http://www.ansar.ru/analytics/krah-arabskoj-mechty (in Russian).
} 
become more and more common. The UK's withdrawal from the project expressed the unwillingness of one of the most important EU members to participate in solving its current issues. There is a growing concern among Russian political scientists and politicians regarding the possibility of dealing with the EU as a single monolith structure. The EU refused linking European integration to Russia's Eurasian integration project (to begin with, the creation of a free trade zone was proposed) $)^{3}$, and moreover, refused creating the "Common European Home" with Russia's participation. The admission to the EU of a number of post-Soviet Eastern European states was held under the pretense of accelerating their democratization, as well as was based on the principle: "joining Europe to confront Russia". The politically motivated sharp expansion of the EU brought to the loss of manageability, turning it into a heterogeneous structure with growing internal contradictions. The migration crisis and the coronavirus pandemic have further led to a discussion of whether the EU is capable of continuing to exist as a single structure, as a subject of world politics ${ }^{4}$.

If the problems of democracy in non-Western countries are considered in the aspect of establishing democratic political regimes, then in such Eastern European EU member states as Poland and Hungary what attracts attention is their recent "retreat" from the democratic values under the migration crisis. If we turn to the ideas of Ivan Krastev and Stephen Holmes, the situation with Hungary turns out to be even more difficult. These authors believe that the Hungarians, who overthrew the Soviet hegemony, are now trying to overthrow the "liberaldemocratic empire administered by Brussels with American backing". The anti-liberalism of the Hungarians "is mostly fueled by nationalist resentment against the post-national European Union which cares nothing for Hungarian identity" [Krastev, Holmes 2019:116-117]. Hence, it is quite clear why the article for our journal by HSE Postgraduate Judas Everett raises the question of whether Poland and Hungary can be considered consolidated democracies. The article shows that Poland and Hungary intend to actively influence the evolution of the European integration project, whether transforming the agenda (as during the migrant crisis), or creating a new European political grouping.

The role of parties in the political life of Great Britain is analyzed in several articles in our issue. The political life of Great Britain is of great interest to political scientists for many reasons. In particular, the country shows a unique combination of the values of British democracy and constitutional monarchy, which was

\footnotetext{
${ }^{3}$ See [Bolonina 2021] for extended analysis of the political reasons for the "non-recognition" of the Eurasian Union by the EU, among which are the strained relations between the Russian Federation and the EU countries, as well as the attitude of Europeans to the EAEU as an instrument for promoting the format of regional integration, alternative to the European one.

${ }^{4}$ Chizhov V. The COVID-19 epidemic: the future of "European unity" and the EU's foreign policy. The Russian International Affairs Council (RIAC). Retrieved June 10, 2020, from https://russiancouncil.ru/analytics-and-comments/analytics/epidemiya-covid-19-budushcheeevropeyskogo-edinstva-i-vneshney-politiki-es/ (in Russian).
} 
seriously put to test during the Brexit period, splitting the country in half between the supporters and the opponents of leaving the EU. The UK is now in the process of forming its own foreign and defense policy, while refusing to discuss it with Brussels [Khakhalkina 2021], and is revising the political ideologies on which party life was based [Aleshin 2019]. Brexit also proved to be a serious challenge for the national identity of a state entity as complex as the United Kingdom of Great Britain and Northern Ireland, since the majority of the population of Scotland and Northern Ireland had no wish of leaving the EU, and the majority of the English were inclined towards the exit. The correlation of European and national (regional) identity is widely discussed and interpreted in the modern political life of France [Alekseev, Fomin 2020] and the United Kingdom ${ }^{5}$.

In this regard, the influence of political ideologies of radicalism and regionalism in the UK under the country's exit from the EU grabbed the attention of our authors. On the example of the UK Independence Party, the article by M.S. Golovin, a researcher from Chelyabinsk State University, reveals how the ideological base of the right-wing radical party was being formed in the initial period after the state's withdrawal from the EU. The article shows how one of the leading far-right parties in the UK constructs its discourse, using the most painful issues for the society in the framework of political struggle. M.V. Grabevnik, a researcher from Perm State National Research University, considers the influence of the ideology of regionalism on the example of the evolution of four regionalist parties in the UK. The author proposes a method for measuring and evaluating regionalism by studying the influence of regionalist parties in different political and institutional conditions

Theoretical and methodological problems of political science are considered in articles devoted to studies of the formation of future political leaders, GRmanagement, and political-psychological characteristics of the heads of Russian regions. Regarding the first problem, MGIMO Postgraduate Jozef Hrabina attempts to determine the scale of the impact of current challenges on future political leaders. The author suggests that the mindset of future leaders will be largely shaped by the shift to multipolarity, in which international relations will be determined by the balance of power logic. He also claims that future politicians will have to deal with emergencies generated by the climate crisis, pandemics and industrial revolutions 4.0 and 5.0 on a global scale. V.V. Romanychev assumes that the sphere of interactions between the government and the business has an interdisciplinary character. However, most of the scientific works on GR studies are narrowly focused, practical and analytical in nature, which does not allow us to consider GR as a system or its embeddedness in the political structure. The author proposes several options for a system methodology, which integrate various methodological

\footnotetext{
${ }^{5}$ Francis Fukuyama [Fukuyama 2018:206, 208] draws special attention to the problem of identity on a global scale. He is concerned that in the EU, each of the 28 member states "continues to zealously defend national prerogatives". To ensure the success of liberal globalization and limit the growth of populism, he sets the task of forming a national identity based on the fundamental ideas of modern liberal democracy.
} 
strategies for a comprehensive analysis of GR activities. Regarding the third problem, A.I. Matiusova, a Postgraduate Student at the Lomonosov Moscow State University, makes an overview of research works on the political and psychological characteristics of the heads of Russian regions. The author concludes that in nowadays Russian political science, within the framework of the politicalpsychological approach, significant materials have been accumulated on the subject characteristics of the Russian governor's corps. However, it is not properly reflected in the current studies on the regional elites of modern Russia.

In general, this issue of our journal complements and expands the picture of the current state of democratic development of Western and non-Western countries in the context of globalization, which is currently at the stage of transitioning from American monopolarity to multipolarity, from imitation of the Western liberal-democratic project to the search for individual development projects. The desire to preserve and strengthen sovereignty, to move away from liberal and market fundamentalism is shown quite convincingly on the example of such different countries as Russia, Turkey, Hungary, Poland. After leaving the EU, the UK also confirmed its desire to pursue an independent policy, not limiting itself to the framework of the European integration project, creating "Global Britain", implementing its own integration project of the British Commonwealth of Nations. The great attention of our authors to the problem of identity was manifested in their interesting conclusions. The authors showed that, in the course of state-building process in the post-Soviet countries, which declared their choice in favor of the liberal-democratic project shortly after the collapse of the Soviet Union, these countries were obliged to construct their new identity by imitating democratic development.

The articles also showed the difficulties faced by the European identity, which has always been characterized as allegedly based on a set of common values, as well as described how the practical implementation of the concept of consolidated democracy in the EU member states is being questioned. Our authors identified the problems of national identity of certain parts of the United Kingdom under the Brexit process, which leads to an increase in the influence of regional political parties and the transformation of right-wing radical movements. Regarding Russia's interests, the materials of this issue allow for outlining the prospects of further research on the ways of establishing the most effective relations with world and regional powers, the opportunities to protect sovereignty and geopolitical interests of Russia, as well as the mechanisms of forming Russia's post-Soviet identity at the national and regional levels.

Received: 05.05.2021

Accepted: 10.05.2021

\section{References}

Alekseev, A.V., \& Fomin, I.V. (2020). "We, the defenders of nations and liberties". How the EU populist radical right discursively constructs identities: the case of the Rassemblement National. Political science (RU), 4, 128-156. DOI: http://www.doi.org/10.31249/poln/2020.04.07 (in Russian). 
Aleshin, A.A. (2019). UK Political Elite Approaches to National Security and Defense after Brexit. South-Russian Journal of Social Sciences, 20(4), 8-26 (in Russian).

Bolonina, A. (2021). Political aspects of "non-recognition of the EAEU by the European Union. Contemporary Europe, 1, 200-208. DOI: 10.15211/soveurope12021200208 (in Russian).

Krastev, I., \& Holmes, S. (2019). The Light that Failed. A Reckoning. Allen Lane.

Pochta, Yu.M. (2020). Islamism and nationalism in the Greater Middle East: Enmity or symbiosis? Asia and Africa Today, 3, 4-11. DOI: 10.31857/S032150750008741-7 (in Russian).

Khakhalkina, E. (2021). "Global Britain": from idea to implementation. Contemporary Europe, 1, 21-32. DOI: 10.15211/soveurope120212132 (in Russian).

Fukuyama, F. (2018). Identity: The demand for dignity and the politics of resentment. New York: Farrar, Straus and Giroux.

\section{About the authors:}

Piotr Dutkiewicz - PhD in Political Science, Professor of Political Science and Director, Centre for Governance and Public Management, Carleton University (Canada) (e-mail: piotr.dutkiewicz@carleton.ca) (ORCID ID: 0000-0001-9749-9116).

Yuriy M. Pochta - Doctor of Philosophy, Full Professor, Professor of the Department of Comparative Politics, Peoples' Friendship University of Russia (RUDN University) (Russian Federation) (e-mail: pochta_yum@pfur.ru) (ORCID ID: 0000-0001-9600-2665).

\section{Сведения об авторах:}

Дуткевич Петр - доктор политических наук, директор Центра государственного управления и общественной политики, профессор Карлтонского университета (Канада) (е-таil: Piotr.Dutkiewicz@carleton.ca)(ORCID ID: 0000-0001-9749-9116)

Почта Юрий Михайлович - доктор философских наук, профессор, профессор кафедры сравнительной политологии Российского университета дружбы народов (e-mail: pochta_yum@pfur.ru) (ORCID ID: 0000-0001-9600-2665). 